\title{
The effect of rumen protozoa on plasma allantoin level and urinary excretion of purine derivatives in sheep
}

\author{
T. Fujihara', M. Iwakuni, M.N. Shem ${ }^{2}$ and T. Hirano
}

Faculty of Life and Environmental Science, Shimane University

Matsue-shi 690-8504, Japan

(Received 20 August 2002; revised version 21 March 2003; accepted 15 July 2003)

\begin{abstract}
An experiment was carried out to examine the effect of rumen protozoa on feed utilization, nitrogen balance and urinary excretion of purine derivatives (PD) in faunated and defaunated lambs fed a hay and concentrate diets. There was no change in digestibilities of dry matter (DM) and organic matter (OM) with or without protozoa, however the digestibilities of crude protein and crude fibre tended to decrease in defaunated lambs, but not significantly $(P>0.05)$. Defaunation decreased nitrogen $(\mathrm{N})$ balance and urinary $\mathrm{N}$ excretion. Consequently, retained $\mathrm{N}$ was higher $(\mathrm{P}<0.05)$ in defaunated than in faunaled lambs. Mean plasma allantoin concentration was higher $(\mathrm{P}<0.05)$ in defaunated $(41.2 \mu \mathrm{mol} / \mathrm{l})$ than in faunated lambs $(25.5 \mu \mathrm{mol} / \mathrm{l})$. Total urinary PD excretion and allantoin excretion were higher $(\mathrm{P}<0.05)$ in the defaunated than in the faunated lambs.

From the above results, it can be concluded that rumen protozoa have an important role in $\mathrm{N}$ utilization, plasma allantoin levels and total PD excretion in lambs.
\end{abstract}

KEY WORDS: rumen protozoa, sheep, purine derivatives, feed utilization

\section{INTRODUCTION}

The major microbial species in the rumen are bacteria and protozoa (Leng and Nolan, 1984) with population of $10^{9}-10^{11}$ and $10^{5}-10^{6}$ per $\mathrm{ml}$ of rumen fluid

\footnotetext{
'Corresponding author: e-mail: fujihara@life.shimane-u.ac.jp

${ }^{2}$ Present address: Faculty of Agriculture, Sokoine University of Agriculture, P.O. Box 3004, Morogoro, Tanzania
} 
respectively (Morimoto, 1969). These microbes are major protein sources for ruminants and their proliferation is very closely related to feed degradation and fermentation in the rumen. Measuring their proliferation and their synthesis of microbial protein is very important when assessing the nutritional status of ruminants.

Several methods are used to estimate the microbial protein synthesized in the rumen. They include, microbial markers (2,4 diaminopimelic acid: DAPA and purine bases) (Hutton et al., 1971; Zinn and Owens, 1986), the tracer method using isotopic substance such as ${ }^{15} \mathrm{~N}$ (Koenig et al., 2000), ${ }^{32} \mathrm{P}$ and ${ }^{35} \mathrm{~S}$ (Stern and Hoover, 1979) and more recently, the indicator method based the use of urinary purine derivatives (PD) (Fujihara et al., 1987; Chen et al., 1990). Nucleic acids from ingested feed are generally completely degraded in the rumen. Therefore, nucleic acids digested in the lower gut are mainly of microbial origin (McAllan, 1982). Nucleic acid $\mathrm{N}$ comprises about $20 \%$ of the total $\mathrm{N}$ content of rumen microbes (Topps and Elliot, 1965) of which $85-95 \%$ is digested in small intestine (Coelho et al., 1972a,b).

In the rumen, bacteria and protozoa ferment fibrous feeds as well as starch and soluble carbohydrates into volatile fatty acids (VFAs) and microbial protein, which are in tum utilized by the host animal. Urinary PD is thus used as an index to estimate the amount of microbial protein synthesized in the rumen. It is important to establish the contribution of protozoal protein to total microbial protein yield in ruminants.

According to Eadie and Hobson (1962), Takenaka et al. (1991) and Nakagawa et al. (1992), protozoa in the rumen tend to influence the number of bacteria, ammonia and VFA production. However, there is a little information on effect of protozoa on nucleic acid metabolism in ruminants (Matsumoto et al., 1991; Fujihara et al., 2002).

An experiment was therefore carried out to investigate the effect of protozoa on feed utilization, $\mathrm{N}$ balance, plasma $\mathrm{PD}$ level and urinary $\mathrm{PD}$ excretion using defaunated and faunated lambs. Part of this research work has briefly described by Fujihara et al. (1999).

\section{MATERIAL AND METHODS}

\section{Animals and diets}

Three crossbred lambs (Japanese Corriedale x Suffolk) of average body weight, $31.6 \pm 1.0 \mathrm{~kg}$, were used in this experiment. The lambs were bottle fed and weaned before being introduced to the experimental diets. During the whole experimental period, the lambs were kept in metabolic crates and were fed on a diet 
comprised of lucerne hay, wheat bran and soyabean meal (Table 1). The energy content of the diet was calculated as about 1.8 times the maintenance requirement for $30 \mathrm{~kg}$ lambs (AFRC, 1994), and dietary protein was also calculated as about 1.5 times the requirement for $200 \mathrm{~g}$ daily gain in growing $30 \mathrm{~kg}$ lambs (ARC, 1965). Half of the daily ration was given at 09.00 and another at $17.00 \mathrm{~h}$. Fresh water and salt licks containing trace elements were freely available to the experimental animals.

TABLE $]$

Chemical composition of milk replacer and feed ingredients used in the experimental diet, \%DM, and daily allowance

\begin{tabular}{lcccc}
\hline Nutrients & $\begin{array}{c}\text { Milk } \\
\text { replacer }\end{array}$ & $\begin{array}{c}\text { Timothy } \\
\text { hay }\end{array}$ & $\begin{array}{c}\text { Soyabean } \\
\text { meal }\end{array}$ & $\begin{array}{c}\text { Wheat } \\
\text { bran }\end{array}$ \\
\hline Crude protein & 24.0 & 7.3 & 44.8 & 18.6 \\
Crude fat & 18.0 & 2.5 & 1.7 & 4.6 \\
Crude fibre & 1.0 & 32.7 & 6.6 & 10.7 \\
Crude ash & 10.0 & 9.4 & 7.3 & 5.5 \\
NFE & 45.7 & 48.1 & 39.6 & 60.5 \\
Ca & 0.8 & 0.3 & 0.3 & 0.1 \\
P & 0.5 & 0.1 & 0.7 & 1.1 \\
& & & & \\
Diet component, \% DM & & 54.0 & 6.0 & 40.0 \\
Daily allowance, gDM/kgBW & & 39.0 & 4.6 & 29.0 \\
\hline
\end{tabular}

${ }^{1}$ nitrogen free extractives

\section{Experimental procedure}

Defaunation of the animals was accomplished by bottle-feeding them on milk replacer for 2 weeks, followed by feeding on a mixed diet (9:1 to 0:10 DM of MR and solid diet) for 10 days (Figure 1). The animals were then fed on a solid diet alone for 1 week. After confirming there was no protozoa in the rumen contents taken through a stomach tube, the digestion and $\mathrm{N}$ balance trial was conducted for a period of five days. Blood samples were collected from the jugular vein just before the morning feed during the digestion trial.

To faunate the animals, 100 protozoa (Holotrichida and Oligotrichina, 1:19) were collected from a different animal fed on a hay and concentrate diet and inoculated onto each of the experimental animals. Concurrent to this, sampling of blood from the jugular vein and urine was carried on the faunated animals. As in the defaunated lambs (on $7^{\text {th }}$ days after inoculation) a 5-day digestion and $\mathrm{N}$ balance trial was also performed, and blood from the jugular vein collected just before the morning feed. 


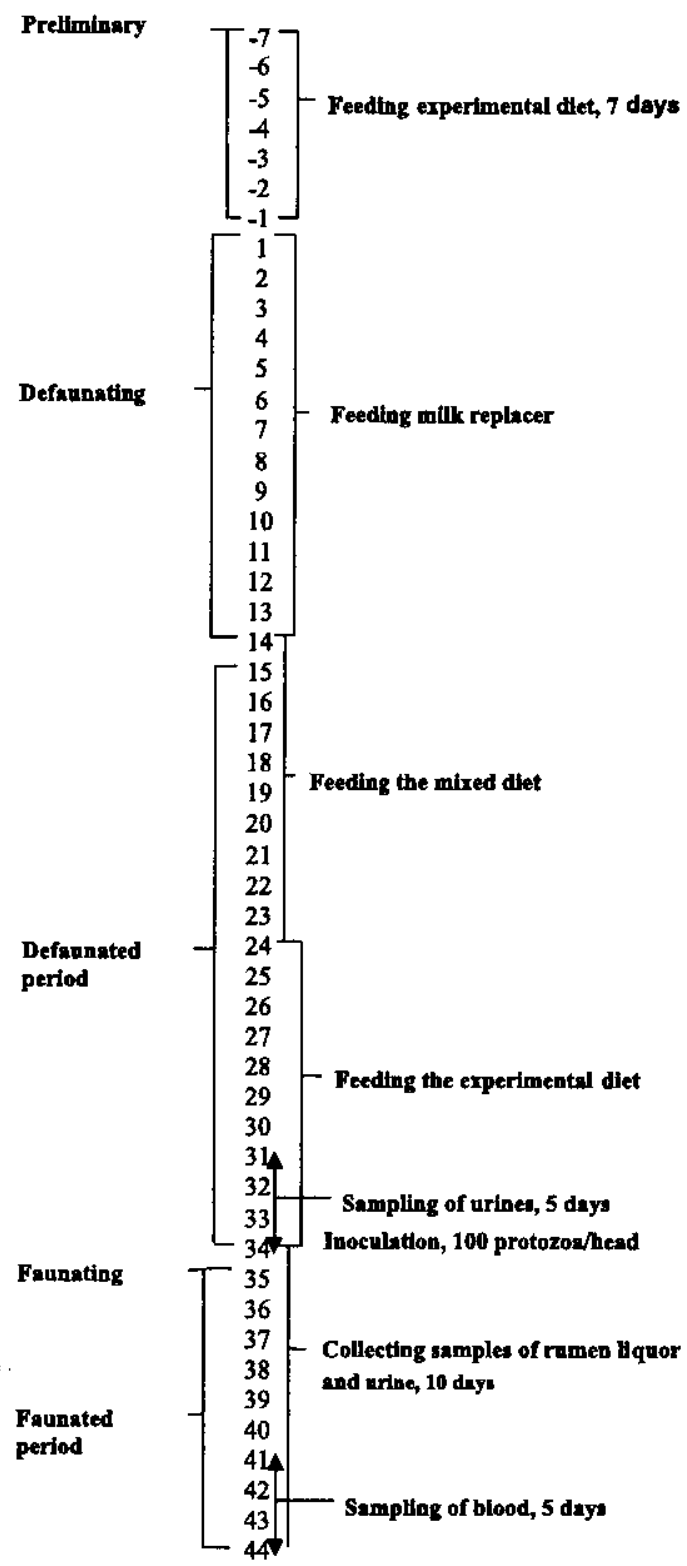

Figure 1. Experimental schedule

* experimental diet (see Table 1) with milk replacer ( $1^{\mathrm{st}} / 1.5: 8.5-2^{\mathrm{nd}} / 3.0: 7.0-3^{\mathrm{rd}} / 4.5: 5.5-4^{\mathrm{th}} / 6.0: 4.0$ $\left.5^{\text {th }} / 7.5: 2.5-6^{\text {th }} / 9.0: 1.0-7^{\text {th }} / 10: 0\right)$

** days

\# milk replacer (see Table 1)

\#\# milk replacer and experimental $d^{\text {ate }}\left(1^{\text {s } 1} / 9: 1-2^{\text {nd }} / 8: 2-3^{\text {rd }} / 7: 3-4^{\text {th }} / 6: 4-5^{\text {th }} / 5: 5-6^{\text {th }} / 4: 6-7^{\text {th }} / 3: 7-8^{\text {th }} / 2\right.$ :

$\left.8-9^{\text {th }} / 1: 1-10^{\text {th }} / 0: 10\right)$ 


\section{Sampling and analytical procedure}

Urine was daily collected with $100-150 \mathrm{ml}$ of $10 \% \mathrm{H}_{2} \mathrm{SO}_{4}$ solution to adjust $\mathrm{pH}$ value below 3.0 before the animals were fed in the morning throughout the entire experimental period and hourly on the final day in each digestion period. During the $1^{\text {st }}-2^{\text {nd }}$ days after inoculation, urine was collected at a 30 min intervals for $48 \mathrm{~h}$ into a container with $10 \% \mathrm{H}_{2} \mathrm{SO}_{4}$ solution with a $\mathrm{pH}$ value of below 3.0. This prevented the decomposition of PD in urine as described by Fujihara (1986) and Fujihara et al. (1991). The samples were then frozen to $-20^{5} \mathrm{C}$ until analysis. Blood was sampled by collecting $10 \mathrm{ml}$ from the jugular vein, centrifuged (1400 $\mathrm{x} g$ for $15 \mathrm{~min}$ ) and the plasma obtained stored in deep freezer (at -40 şC) until analysis. Blood sampling was conducted at $0,1,3,5$ and $7 \mathrm{~h}$ after the moming feeding on the final day of each digestion trial. This also was repeated on the $1^{\text {st }}-7^{\text {th }}$ days after inoculation, before every morning feed. However, blood sampling was conducted at $0,2,4,6$, and $8 \mathrm{~h}$ after morning feed on the $1^{\text {st }}$ and $2^{\text {nd }}$ days after inoculation,

Nitrogen $(\mathrm{N})$ in feed, faeces and urine was analyzed using the Kjeldahl method, while the contents of crude fat, crude fibre and crude ash in the feed and faeces were determined by AOAC method (AOAC, 1960). The PD in urine and plasma was analyzed by the methods of Young and Conway (1942) and Fujihara et al. (1987).

Test for significance of difference between the two groups (faunated and defaunated) was done using the t-test.

\section{RESULTS AND DISCUSSION}

\section{Nutrient digestibility and $N$ balance}

Table 2 shows apparent digestibility and nitrogen balance in lambs fed hay and concentrate diet. The digestibilities of dry matter (DM) and organic matter (OM) were almost the same in both defaunated and faunated lambs. The digestibilities of crude protein (CP) and crude fibre tended to be slightly lower in defaunated than in faunated lambs. The fact that CP digestibility tended to increase in faunated lambs would be probably due to the effect of proteolytic activities of protozoa, and also due to an ability of protozoa to engulf feed particles in the rumen (Coleman, 1983). The decrease in crude fibre digestibility in defaunated lambs might be due to the decrease in ruminal $\mathrm{pH}$ values and also in ruminal ammonia concentrations caused by defaunation.

$\mathrm{N}$ balance data in Table 2 shows that faecal $\mathrm{N}$ excretion tended to slight increase in the defaunated lambs, but not significantly $(\mathrm{P}>0.05)$. Similar trend was also reported by Itabashi et al. (1984) using the defaunated goats. 
TABLE 2

Apparent digestibility of feed and nitrogen balance of lambs in defaunated and faunated period

\begin{tabular}{lcccc}
\hline \multirow{2}{*}{ Indices } & \multicolumn{2}{c}{ Defaunated } & \multicolumn{2}{c}{ Faunated } \\
\cline { 2 - 5 } & mean & s.e. & mean & s.e. \\
\hline Digestibility, \% & & & & \\
$\quad$ dry matter & $62.50^{1}$ & 2.05 & 62.18 & 0.36 \\
organic matter & 64.10 & 1.88 & 64.41 & 0.37 \\
crude protein & 71.27 & 0.99 & 73.88 & 0.38 \\
ether extract & 63.32 & 2.00 & 60.87 & 2.27 \\
crude fibre & 56.29 & 3.41 & 60.20 & 0.70 \\
& & & & \\
$\mathrm{~N}$ balance, g/d/BW ${ }^{0.75}$ & & & & \\
intake & 1.52 & 0.03 & 1.46 & 0.03 \\
faeces & 0.44 & 0.02 & 0.38 & 0.01 \\
urine & $0.50^{\mathrm{a}}$ & 0.02 & $0.57^{\mathrm{b}}$ & 0.02 \\
absorbed & 1.08 & 0.01 & 1.08 & 0.02 \\
retained & $0.58^{\mathrm{a}}$ & 0.02 & $0.51^{\mathrm{b}}$ & 0.01 \\
absorbed/intake, \% & 71.27 & 0.99 & 73.88 & 0.38 \\
retained/intake, \% & 38.26 & 1.67 & 35.22 & 1.13 \\
retained/absorbed, \% & 53.65 & 1.79 & 47.68 & 1.48 \\
\hline
\end{tabular}

' mean of 3 lambs

${ }^{a, b}$ values In the same column with different superscripts differ significantly $(\mathrm{P}<0.05)$

The urinary $\mathrm{N}$ excretion was markedly low $(\mathrm{P}<0.05)$ in defaunated as compared to that in faunated lambs. Consequently, retained $\mathrm{N}$ was higher $(\mathrm{P}<0.05)$ in the former than in the latter. These findings clearly show that the utilization of absorbed $\mathrm{N}$ was more efficiently done in defaunated than that in faunated animals. Matsumoto et al. (1991) also reported urinary $\mathrm{N}$ excretion was smaller in defaunated goats than in faunated one when they were fed on mixed hay $(800 \mathrm{~g} / \mathrm{d} / \mathrm{head})$ and concentrates $(500 \mathrm{~g} / \mathrm{d} /$ head $)$ including $1 \%$ of urea.

\section{Effect of protozoa on urinary $N$ excretion}

Figure 2 shows the daily urinary $\mathrm{N}$ excretion during the defaunation and faunation periods in $\mathrm{g}$ per $\mathrm{kg}$ metabolic body weight. Urinary $\mathrm{N}$ excretion decreased markedly during the 10 to 14 days $\left(1.26-0.58 \mathrm{~g} / \mathrm{d} / \mathrm{BW}^{0.75}\right)$ after the defaunated lambs were fed on milk replacer (MR) and reached peak level on the 16 day $(1.34 \mathrm{~g} / \mathrm{d} /$ $\mathrm{BW}^{0.75}$ ). After that there was a gradual decrease in daily urinary $\mathrm{N}$ excretion until inoculation (on 34 day) and gradually increased up to the 3 to 6 days reaching almost constant level at the end of the digestion trial. Results in the present study are in agreement with that of Matsumoto et al. (1991), and are opposite with that of Fujihara ct al. (2002) using goats. Therefore from the above evidence, there is 


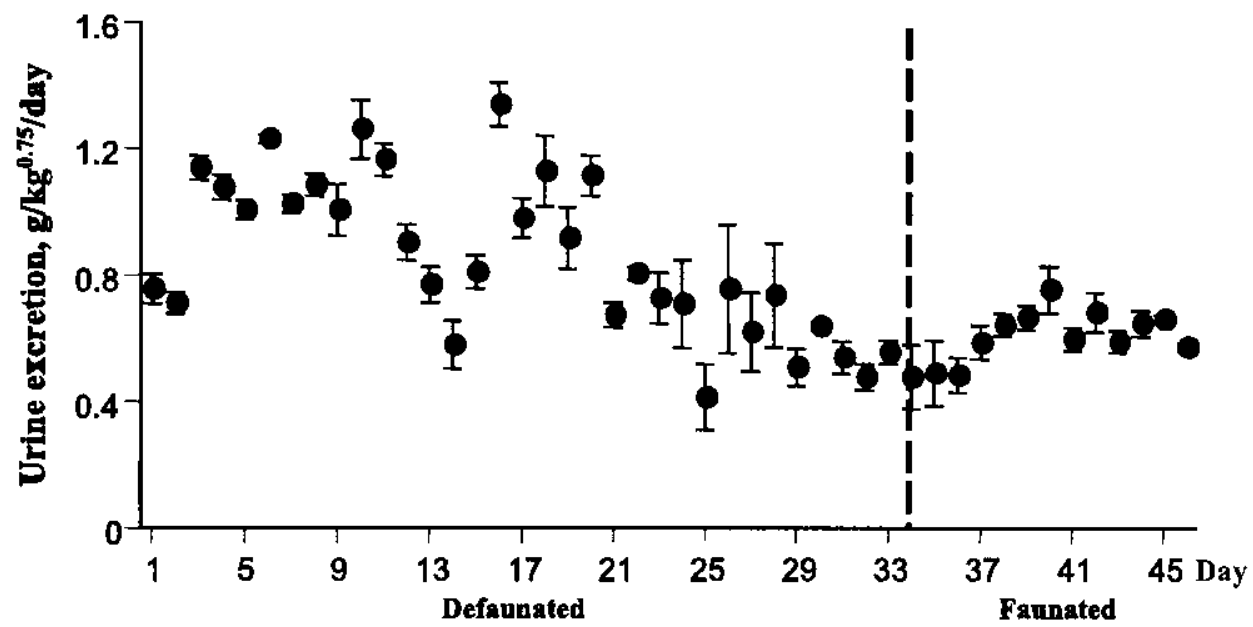

Figure 2. Daily urinary nitrogen excretion during the experimental period

no relationship between protozoa population in the rumen and urinary $\mathrm{N}$ excretion when there is a lapse in time after inoculation.

\section{Effect of protozoa on plasma allantoin concentration}

Mean values of plasma allantoin concentration were higher $(\mathrm{P}<0.05)$ in defaunated than faunated lambs (Table 3 ). This clearly indicates that the amount of nucleic acid metabolized to be higher in defaunated than in faunated lambs. In our previous experiment using goats, contrarily, there was no clear difference in defaunated and faunated periods (Fujihara et al., 2002).

TABLE 3

Plasma allantoin levels in lambs in defaunated and faunated periods

\begin{tabular}{lc}
\hline Lambs & Allantoin, $\mu \mathrm{mol} / 1$ \\
\hline Defaunated & $41.20^{\mathrm{a}} \pm 1.02^{\prime}$ \\
Faunated & $25.50^{\mathrm{b}} \pm 1.04$ \\
\hline
\end{tabular}

mean \pm S. E. of 3 lambs

${ }^{a, b}$ values In the same column with different superscripts differ significantly $(\mathrm{P}<0.01)$

Figure 3 shows the daily changes in plasma allantoin levels with time after inoculation, and there were no clear trend as same as the result of our previous experiment, in which there were also no increases or decreases in plasma allantoin level 


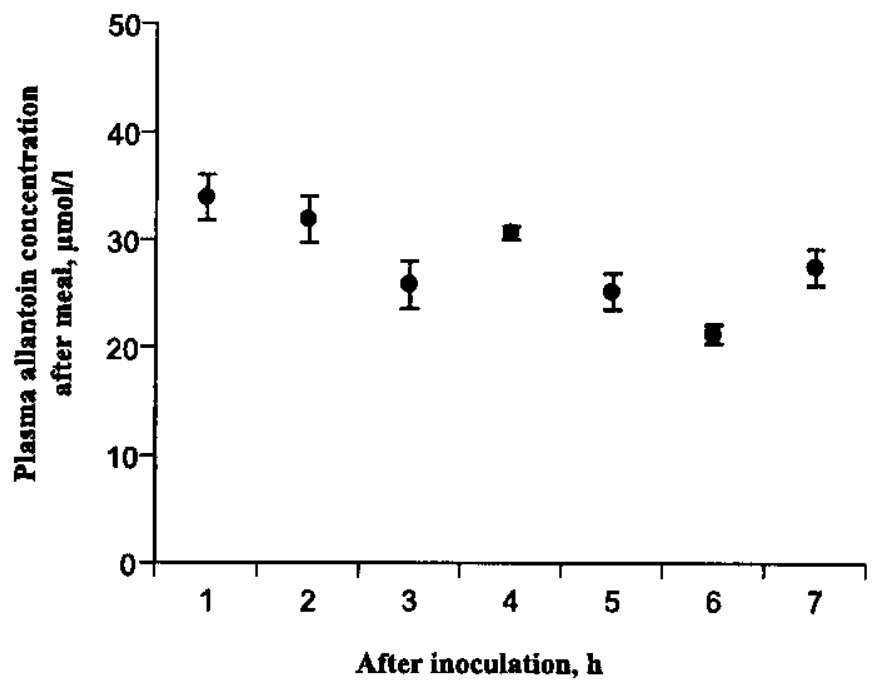

Figure 3. Daily changes in plasma AN levels with a decrease in plasma AN with time after inoculation

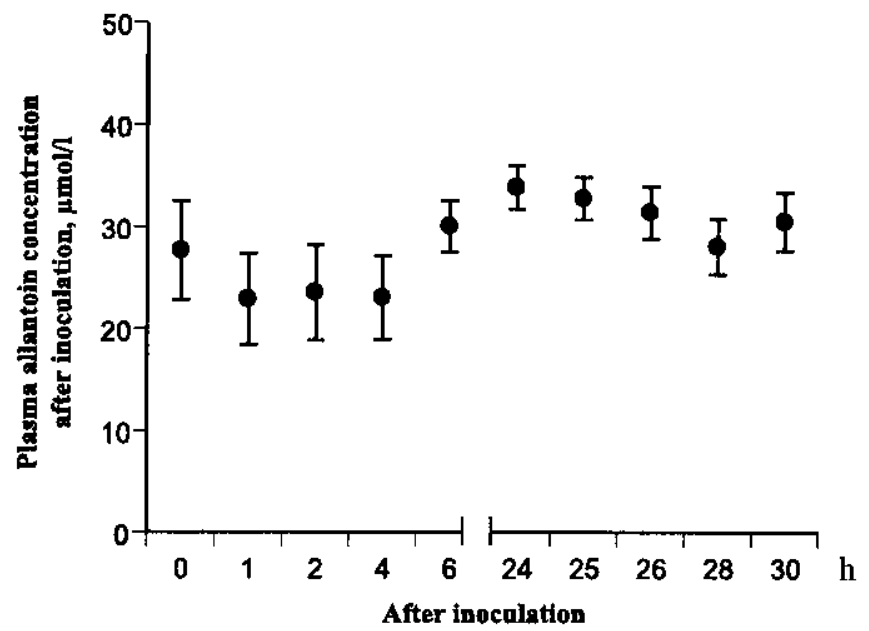

Figure 4. Changes in plasma AN levels during $30 \mathrm{~h}$ after inoculation

with time after inoculation in goats (Fujihara et al., 2002). As shown in Figure 4, the changes in plasma allantoin levels for the three lambs during $30 \mathrm{~h}$ after inoculation was low at one hour reaching peak levels at $6 \mathrm{~h}$ after inoculation and gradually decreasing thereafter. 


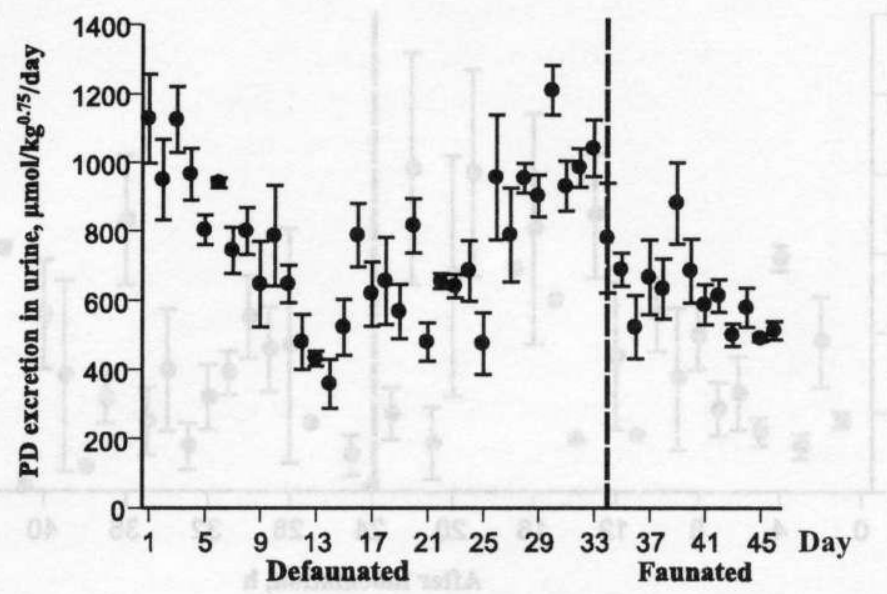

Figure 5. Changes in urinary PD excretion throughout the experimental period

The above findings show that an effect of protozoa on plasma allantoin level is not clear, however, it should be that plasma allantoin level is closely related to metabolism of nucleic acid in the rumen and/or lower gut caused by the changes of microbial population in the rumen as protozoa feed by engulfing bacteria (Koenig et al., 2000).

\section{Urinary PD excretion through entire experimental period}

Figure 5 shows the changes in urinary PD excretion throughout the experimental period. There was a gradual decrease in urinary $\mathrm{PD}$ excretion to the 14 day after which it increased until the 30 day after initiation of the experiment. These findings show that the changes in urinary PD excretion rate were influenced by the feeding regimes used. Lambs were initially fed on MR followed by feeding on the mixed diet. The metabolism of nucleic acids thus differed depending on the concomitant changes in microbial population in the rumen due to diet influence. Evidence from literature using lambs nourished by intragastric nutrition (Fujihara, 1986; Chen et al., 1997), show the existence of a direct relationship between nucleic acid supply and urinary PD excretion.

\section{Changes in urinary PD excretion after inoculation}

Figure 6 shows hourly PD excretion into urine during 2 days after inoculation. PD excretion increased up to the $19-22 \mathrm{~h}$, and then decreased gradually until $48 \mathrm{~h}$. This is because there was "a leading period" until 19-22 h after inocu- 


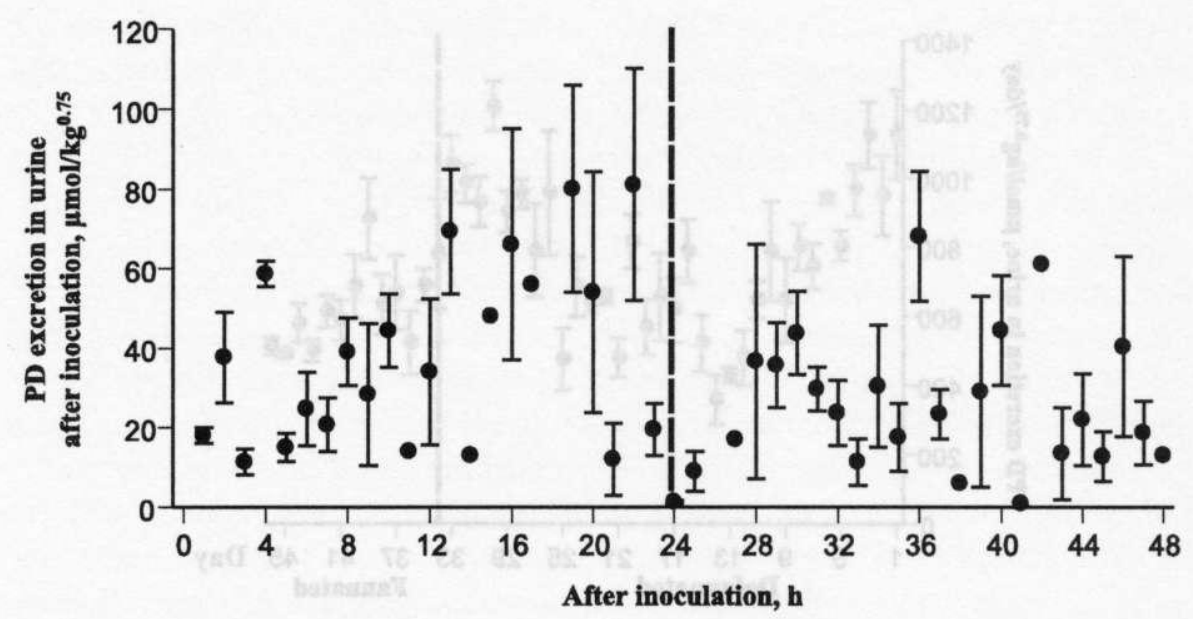

Figure 6. Changes in hourly PD excretion into urine during 2 days after inoculation

lation after which there was a remarkable proliferation of protozoa. The mean value of urinary PD excretion up to $22 \mathrm{~h}$ after inoculation was 596, 696 and 730 $\mu \mathrm{mol} / \mathrm{BW}^{0.75} / \mathrm{d}$ and the corresponding values for the $23-48 \mathrm{~h}$ was 341,622 and $646 \mu \mathrm{mol} / \mathrm{BW}^{0.75} / \mathrm{d}$ for the three lambs, respectively. Thus urinary PD excretion decreased markedly on 2 day compared to that in first day after inoculation.

On the changes in daily urinary PD excretion during 12 days after inoculation, there was quite big variation in urinary PD excretion up to the 6 day, however the changes in urinary PD excretion was relatively small between the 7 and 12 day, that might have been reflected a stable condition as a whole in the rumen microbial population (see Figure 5).

\section{Urinary PD excretion in defaunated and faunated period}

Table 4 shows the mean values of urinary PD in the defaunated and faunated lambs. Urinary allantoin and total $\mathrm{PD}$ excretion were higher $(\mathrm{P}<0.05)$ in the defaunated than in the faunated animals, whereas the excretion of uric acid into urine was almost the same in both periods. Similar results were also reported by Fujihara et al. (2002) using goats. These findings clearly show that protozoa have a negative effect on urinary PD excretion due to reduced nucleic acid synthesis in the rumen. Protozoa engulf bacteria in the faunated animals resulting in low levels of PD excretion, especially that of allantoin. There is no effect on the excretion of uric acid both in faunated and defaunated lambs. 
TABLE 4

Urinary PD excretion of lambs in defaunated and faunated periods

\begin{tabular}{lccc}
\hline \multirow{2}{*}{ Lambs } & Allantoin & Uric acid $^{2}$ & Total PD \\
\cline { 2 - 4 } & \multicolumn{3}{c}{$\mu \mathrm{mol} / \mathrm{d} / \mathrm{kgBW}^{0.75}$} \\
\hline Defaunated & $726.5^{\mathrm{a}} \pm 48.5^{1}$ & $263.9 \pm 15.6$ & $989.5^{\mathrm{a}} \pm 52.2$ \\
Faunated & $334.6^{\mathrm{b}} \pm 25.1$ & $204.7 \pm 34.4$ & $539.3^{\mathrm{b}} \pm 19.3$ \\
\hline
\end{tabular}

1 mean \pm S.E. of 3 lambs

2 uric acid, xanthine plus hypoxanthine

${ }^{\mathrm{a}, \mathrm{b}}$ values In the same column with different superscripts differ significantly $(\mathrm{P}<0.05)$

\section{CONCLUSIONS}

From the results obtained in the present study, it can be concluded that protozoa have an effect on nitrogen utilization, in particular purine metabolism in lambs. To obtain detailed results on the proliferation of protozoa and their effect on purine metabolism after inoculation, frequent checks on the number of rumen protozoa and urinary PD level is necessary within a few days after inoculation.

\section{ACKNOWLEDGEMENT}

Authors are very grateful to Mr. K. Miyata for his helpful assistance during the course of the experiment.

\section{REFERENCES}

Agricultural and Food Research Council, 1993. Energy and Protein Requirements of Ruminants. An advisory manual prepared by the AFRC Technical Committee on Responses to Nutrition. CAB International, Wallingford (UK)

Agricultural and Food Research Council. 1965. The Nutrient Requirements of Farm Livestock. No. 2. Ruminants. London: Agricultural Research Council (UK)

AOAC, 1960. Association of Official Analytical Chemists, Official Method of Analysis. $9^{\text {th }}$ Edition. Washington, DC, pp. 283-288

Chen X.B., Fujihara T., Nakamura K., Mawuenyegah P.O., Franklin M.F., Kyle D.J., 1997. Response of urinary and plasma purine derivatives to various rates and infusion patterns of purines in sheep nourished by intragastric infusion. J. Agr. Sci. 129, 343-352

Chen X.B., Hovell F.D. DEB., Ørskov E.R., Brown D.S., 1990. Excretion of purine derivatives by ruminants: effect of exogenous nucleic acid supply on purine derivatives excretion by sheep. Brit. J. Nutr. 63, 131-142 
Coelho Da Silva J.F., Seeley R.C., Beever D.E., Prescott J.H.D., Armstrong D.G., 1972a. The effect in sheep of physical form and stage of growth on the sites of digestion of a dried grass. 2. Sites of nitrogen digestion. Brit. J. Nutr. 28,357-371

Coelho Da Silva J.F., Seeley R.C., Thomson D.J., Beever D.E, Armstrong D.G., 1972b. The effect in sheep of physical form on the sites of digestion of a dried lucerne diet. 2. Sites of nitrogen digestion. Brit. J. Nutr. 28, 43-61

Coleman G.S., 1983. Hydrolysis of fraction 1 leaf protein and casein by rumen entodiniumorphid protozoa. J. Appl. Bacteriol. 55, 111-118

Eadie M.J., Hobson P.N., 1962. Effect of the presence or absence of rumen ciliate protozoa on the total rumen bacterial count in lambs. Nature 193, 503-505

Fujihara T., 1986. Utilization of microbial protein and urinary PD excretion in ruminants (in Japanese). Proc. Jpn. Soc. Anim. Nutr. Metabol. 30, 1-16

Fujihara T., Iwakuni M, Miyata K., 1999. The effect of numen protozoa on plasma allantoin level and urinary excretion of purine derivatives in sheep. Proceedings of IX ${ }^{\text {th }}$ International Symposium of Ruminant Physiology, Pretoria (South Africa). S. Afr. J. Anim. Sci. 29 (ISRP), 137-138

Fujihara T., Matsui T., Harumoto T., 1991. Urinary excretion of purine derivatives and blood plasma level of allantoin in sheep and goats during fasting. Proceedings of $6^{\text {th }}$ International Symposium on Protein Metabolism and Nutrition, pp. 170-172

Fujihara T., Oka N., Todoroki M., Nakamura K., 1994. The effect of rumen protozoa on the urinary excretion of purine derivatives in goats. Proc. Soc. Nutr. Physiol. 3, 234

Fujihara T., Ørskov E.R., Reeds P.J., Kyle D.J., 1987. The effect of protein infusion on urinary excretion of purine derivatives in ruminants nourished by intragastric nutrition. J. Agr. Sci. 109, 7-12

Fujihara T., Todoroki M., Nakamura K., 2002. The effect of rumen protozoa on the urinary excretion of purine derivatives in goats. J. Agr. Sci. (in press)

Hutton K., Bailey F.J., Annison E.F., 1971. Measurement of the bacterial nitrogen entering the duodenum of the ruminant using diaminopimelic acid as a marker. Brit. J. Nutr. 25,165-173

Itabashi H., Kobayashi T., Matsumoto M., 1984. The effect of rumen ciliate protozoa on energy metabolism and some constituents in rumen fluid and blood plasma of goats. Jpn. J. Zootech. Sci. 55,248-256

Koenig K. M., Newbold C. J., McIntoshu F. M., Rode L. M., 2000. Effects of protozoa on bacterial nitrogen recycling in the rumen. J. Anim. Sci. 78, 2431-2445

Leng R. A., Nolan J. V., 1984. Nitrogen metabolism in the rumen. J. Dairy Sci. 67, 1072-1089

Matsumoto M., Kobayashi T., Itabashi H., 1991. Effects of rumen ciliate protozoa on urinary allantoin excretion in goats. Anim. Sci. Technol. (Jpn.) 62, 939-946

McAllan A.B., 1982. The fate of nucleic acid in ruminants. Proc. Nutr. Soc. 41, 309-317

Morimoto H., 1969. Animal Nutrition (in Japanese). Tokyo, Japan: Yokendo Co. Ltd., pp. 214-216

Nakagawa T., Kobayashi Y., Wakita M., Hoshino S., 1992. Effects of defaunation and inoculation of ciliates on some rumen parameters and feed utilization in sheep (in Japanese). Anim. Sci. Technol. 63, 964-969

Stern M.D., Hoover W.H., 1979. Methods for determining and factors affecting rumen microbial protein synthesis: A review. J. Anim. Sci. 48, 1590-1603

Takenaka A., Matsumoto M., Kobayashi T., Itabashi H., 1991. The effect of Dastrica, Epitodenium and Entodenium on ruminal bacteria and fermentation pattern in calves. Anim. Sci. Technol. $62,368-374$

Topps J. H., Elliott R. C., 1965. Relationship between concentrations of ruminal nucleic acid and excretion of purine derivatives by sheep. Nature 205, 498-499 
Young E.G., Conway C.F., 1942. On the estimation of allantoin by the Rimini-Schryver reaction. J. Biol. Chem. 142, 839-852

Zinn R.A., Owens F.N., 1986. A rapid procedure for purine measurement and its use for estimating net ruminal protein synthesis. Can. J. Anim. Sci. 66, 157-166

\section{STRESZCZENIE}

Wpływ pierwotniaków żwacza na poziom alantoiny w plazmie krwi oraz wydalanie pochodnych purynowych w moczu owiec

Celem doświadczenia było zbadanie wpływu pierwotniaków żwacza na wykorzystanie paszy, bilans azotu oraz wydalanie w moczu pochodnych purynowych (PD) przez faunowane i defaunowane jagnięta otrzymujace dawki złożone z siana i paszy treściwej.

Strawność suchej masy (s.m.) i substancji organicznej (OM) nie różniła się między jagniętami $\mathrm{z}$ lub bez pierwotniaków, natomiast stwierdzono tendencję obniżenia strawności białka ogólnego $i$ włókna u defaunowanych owiec, lecz nie potwierdzonej statystycznie ( $\mathrm{P}>0,05)$. W wyniku defaunacji obniżył się bilans azotu (N) oraz wydalanie $\mathrm{N}$ w moczu, a w konsekwencji ilość zatrzymanego $\mathrm{N}$ $\mathrm{u}$ defaunowanych zwierząt była większa $(\mathrm{P}<0,05)$ niż u faunowanych. Średnie stężenie alantoiny w plazmie krwi było większe $(\mathrm{P}<0,05)$ u defaunowanych niż faunowanych owiec, 41,2 vs $25,5 \mu \mathrm{mol} / \mathrm{l}$. Suma wydalonych $\mathrm{PD}$ oraz alantoiny była większa $(\mathrm{P}<0,05) \mathrm{u}$ defaunowanych jagniąt.

Na podstawie otrzymanych wyników można stwierdzić, że pierwotniaki żwacza odgrywają ważną rolę w wykorzystaniu N przez jagnięta, wplywają na poziom alantoiny w plazmie krwi oraz wydalanie PD w moczu. 